\title{
Student Teachers Difficulties in Teaching English to Hotel Staff
}

\author{
Maria Christina EkoSetyarini \\ Universitas Kristen Satya Wacana \\ maria.setyorini@staff.uksw.edu
}

\begin{abstract}
Professional English teachers often find it difficult when they have to teach English for Specific Purpose (ESP) as they need to do extra works like doing need analysis and creating the specific syllabus before teaching to make sure that the teaching-learning process will go smoothly. Student teachers, who have less experience in teaching, are likely to face greater difficulties in teaching ESP. The study aims at finding out student teachers difficulties in teaching English to hotel staff. Therefore, eight student teachers who recently taught English to hotel staff in their teaching practicum were asked to write about their experience in teaching in form of reflections. The study reveals that the eight student teachers who taught different hotel staff in four customer related divisions, front office, housekeeping, marketing, and food and beverage face similar difficulties. The difficulties are mostly related to the hotel staff. They are teaching facilities, time management, different levels of English proficiency, and low self-efficacy. It is expected that the finding can be useful for student teachers who will do their teaching practicum in hotels, also for those who are interested in studying ESP especially in teaching English to hotel staff.
\end{abstract}

\section{ARTICLE HISTORY}

Received 05 May 2018

Accepted 16 August 2018

\section{KEYWORDS}

Student teachers; difficulties; ESP

\section{Introduction}

Recently the demand of Teaching English for Specific Purpose (TESP) Indonesia has increased rapidly. This probably related to the formation of ASEAN Economic Community (AEC) in 2015 which. Since AEC allows people from other ASEAN countries to come and work in an ASEAN country, people have started to be aware of the urge of learning English as a mean of international business communication. As a consequence many people want to join English course to study English for their specific purposes. Many working institutions have also tried to provide English trainings for their workers. This has made the demand of TESP teachers increasing.

As an attempt to fulfil the demand of TESP teachers, our English Language Teaching Program has decided to equip students with the experience of TESP, and therefore, has done some changes in our curriculum. The changes include the insertion

a new course, i.e. The Practice of TESP in which students should do a need analysis and micro teachings, and the addition of some hotels as the teaching practicum sites. 
Huang (2008) mentions that there are four dimensions in the curriculum of English for tourism and hospitality namely English for Food and Beverage services, English for Air Flight Services, English for Hotel Services, and English for Tour Managers and Guides. Our study program, however, choose to focus only to one dimension i.e. English for Hotel Services. This means, students who are interested in teaching ESP have to take the Practice of TESP course and do their teaching practicum in hotels. Here, the students are required to teach English to hotel staff for about three months.

During the teaching practicum period, our students are expected to be able to teach hotel staff in a good way, whereas we know that TESP requires the teachers to do more effort in teaching. The teachers not only have to deal with the day to day teaching activities but they also have to "deals with needs analysis, syllabus design, materials writing or adaption and evaluation." (Hutchinson \& Waters, 1992, p. 157). This can be hard for student teachers who are still learning about teaching. The writer, therefore, interested to see the difficulties that the student teachers may face in teaching English to hotel staff.

While there have been many works done in the area of TESP especially those related to English for Hotel Services, there are not many research related to student teachers have been done. Zahedpisheh et. al. (2017) have written about the feature of English for tourism. They provide an overview on the purpose of teaching ESP (English for Specific Purposes) and ETP (English for Tourism Purposes) to the learners and users. Lin et. al. (2013)have also done a study on Hotel Employees in Taiwan. They focus on the relationship between background demographic characteristics, ESP, learning styles, and language proficiency. Their work, however, have no relation with student teacher or teaching practicum. Meanwhile, in his study, Bracaj (2014) only discuss TESP teacher training in general. This is another reason why the writer wanted to do a study on student teachers difficulties in teaching ESP. The aim of the study is to reveal the difficulties faced by student teachers in doing teaching English for hotel staff. The study is expected to be useful for student teachers planning to do their teaching practicum in hotels. It is also expected to be useful for those who are interested in teaching ESP especially in teaching English to hotel staff. 


\section{Literature Review}

\section{What is ESP?}

Referring to the classic definition by Hutchison \& Waters (1987) in which ESP meansa language learning approach based on learners' needs ESP may be viewed as teaching English in accordance with the learner needs. Dudley-Evans, however, view teaching ESP as having a more dimension than just dealing with the learners' need since he says that ;

The establishment of needs is based on the activities that the learner has to perform in English, but this is only the first step; once we know which skills are needed and what activities learners will be engaged in, we need to carry out a more focused analysis of the genres and language involved in each of these skills and activities. (Dudley Evans,1998, p2)

Similarly Basturkmen (2006) mentioned that the teaching of ESP includes the features of language or to develop the competencies needed to function in a discipline, profession, or workplace. This means that that teaching ESP is a complex process. It cannot be done only by focusing on the learners needs but also by considering what activities a teacher can provide to make the learners competence the certain skill needed.

The complexity of teaching ESP, as Belcher (2009) claims, has increased along with the development of the learners' need as a result of the urge to communicate across languages in areas such as commerce and technology. Belcher (2009) further mentioned that the teaching of ESP has expanded to include other areas such as English for academic purposes (EAP), English for occupational purposes (EOP), English for vocational purposes (EVP), English for medical purposes (EMP), English for business purposes (EBP), English for legal purposes (ELP), and English for sociocultural purposes (ESCP).

Teaching ESP, therefore, can be viewed as a process of teaching English which require teachers to consider many factors. The learners' practical needs come first. Other factors like the language skill, the language functions, and the classroom activities are next. Another thing needs to be taken into account is the specific area in which teaching ESP is done. 


\section{The Role of ESP Teachers}

ESP teachers should be those who have passion in teaching because these teachers have many important roles. Basturkmen (2017) see that the implementation of ESP includes a lot of tasks, such as finding out what the learners need and choosing which specific discourse to teach, developing courses and materials as well as teaching. This means that ESP teachers need to play the role as researchers, material developers in addition of being a teacher. Dudley-Evans \& St. John (1998) even mention that there are five teachers' role in ESP. They are teacher, course and material designer, collaborator, researcher, and evaluator.

Dudley-Evans \& St. John (1998) further explain that related to their role as teacher, ESP teachers have to be a specialist in communication as the teaching of ESP is beyond the teaching of language. While as course and material designers, ESP teachers have the responsibility to choose the teaching materials, or to provide the materials if they can not find any available one. They also have to think about how to deliver the material successfully to the learner.

As collaborators ESP teachers are required to engage the course with the learners professional activities. They are also required to work hand in hand with subject specialist to prepare the suitable material. Whereas evaluator, ESP teachers have to do two kinds of evaluation. The first one is the evaluation of students' progress in learning. The second one is the evaluation of the course and teaching materials.

\section{Difficulties in TESP}

Since ESP teachers have many roles to play, they tend to face many difficulties in teaching. Fălăuş (2016) state that there are two difficulties in TESP. The first challenge he mentions is course design. Designing a course in ESP, according Fălăuş(2016) requires the teachers to do need analysis, to arrange the syllabus, and to decide the appropriate methodology to be used in teaching which require teacher to adjust with the characteristics of the learners. Meanwhile, the second challenge is the five roles mentioned in the previous section.

Different from Fălăuş (2016), Hoa and Mai (2016) provide a more extensive explanation about the difficulties in TESP. They classify the challenges into three major categories, challenges related to students, challenges related to teachers, and difficulties related to the environment or others. The difficulties included in the three categories can be seen from Table 1 . 
Table 1.Categories of Difficulties in TESP according to Hoa and Mai (2016)

\begin{tabular}{|c|c|c|}
\hline \multicolumn{3}{|c|}{ Difficulties } \\
\hline related to students & related to teachers & $\begin{array}{c}\text { related to } \\
\text { environment/others }\end{array}$ \\
\hline $\begin{array}{l}\text { Students' } \\
\text { demographiccharacteristics } \\
\text { and demands of } \\
\text { learningEnglish for } \\
\text { specificpurposes }\end{array}$ & $\begin{array}{l}\text { Quality of lectures and } \\
\text { textbooks }\end{array}$ & Lack of teaching materials \\
\hline Students' English proficiency & $\begin{array}{l}\text { Teachers' Qualificationand } \\
\text { Teaching Methods }\end{array}$ & $\begin{array}{l}\text { Classes with too large:student } \\
\text { number }\end{array}$ \\
\hline $\begin{array}{l}\text { The difference between } \\
\text { English and the students' first } \\
\text { language }\end{array}$ & $\begin{array}{l}\text { Lack of Theoretical } \\
\text { framework to support teaching } \\
\text { English for specific purposes }\end{array}$ & Heavily focused examination \\
\hline $\begin{array}{l}\text { The lack of students' } \\
\text { vocabulary }\end{array}$ & & \\
\hline $\begin{array}{l}\text { Dependence on dictionary and } \\
\text { lack of skills in using } \\
\text { dictionary }\end{array}$ & & \\
\hline $\begin{array}{l}\text { Students' low reading, } \\
\text { listening, speaking and } \\
\text { writing skills }\end{array}$ & & \\
\hline
\end{tabular}

The three major categories created by Hoa and Mai (2016) were used to classify the data found from the students'reflections.

\section{Methodology}

This study is a qualitative research. Snape \& Spencer (2003, p.3) state that qualitative researches "are directed at providing an in-depth and interpreted understanding of the social world of research participants by learning about their social and material circumstances, their experiences, perspectives and histories. Similarly, Hancock et. al. (2009) reveal that qualitative researches try to explain social phenomena to help us to understand the world in which we live in. It concerns with people's behavior, peoples' attitudes and opinions, peoples' cultural practices, and peoples' events. In this paper, the study focused on describing student teachers' experiences in teaching English for hotel staff.

To collect the data, 8 student teachers who did their teaching practicum in a hotel in Central Java, Indonesia were asked to write reflections. According to Bolton: 
Reflection is an in-depth consideration of events or situations outside of oneself: solitarily, or with critical support. The reflector attempts to work out what happened, what they thought or felt about it, why, who was involved and when, and what these others might have experienced and thought and felt about it. (2009, p.13).

The reflections that the students-teachers wrote include the story about the teaching difficulties as well as the lesson they learn from their teaching practicum experience. The eight student teachers were expected to write various difficulties in their teaching as they taught hotel staff in four different divisions, front office (FO), housekeeping (HK), marketing (MT), food and beverage (FB), each division had two student teachers.

\section{Findings and Discussion}

Having the data collected and analysed, the study found an interesting fact. The student teachers participated in the study, expressed similar difficulties in teaching English for Hotel Staff. Though the eight students were divided into four groups to teach four different divisions in the hotel, each group revealed that there are four kinds of difficulties. They are mostly related to the hotel staff. They are teaching facilities, time management, different levels of English proficiency, and low selfefficacy. This can be seen in Table 2 .

Referring to the classification of TESP difficulties proposed by Hoa and Mai (2016), the findings of the study fall into two categories, difficulties related to students which include time management, different level of proficiency and selfefficacy. and difficulties related the environment/others i.e. teaching facilities. The study also found that the student teachers did not write about the difficulties related to themselves as the teachers. 
Table 2.Difficulties in TESP Found in the Study

\begin{tabular}{|c|c|c|c|c|}
\hline & $\begin{array}{l}\text { Teaching } \\
\text { facilities }\end{array}$ & $\begin{array}{c}\text { Time } \\
\text { Management }\end{array}$ & $\begin{array}{c}\text { Different } \\
\text { levels of } \\
\text { English } \\
\text { Proficiency }\end{array}$ & $\begin{array}{c}\text { Self } \\
\text { Efficacy }\end{array}$ \\
\hline \multicolumn{5}{|l|}{$\mathrm{FO}$} \\
\hline Student teacher A & $\sqrt{ }$ & $\sqrt{ }$ & $\sqrt{ }$ & $\sqrt{ }$ \\
\hline Student teacher B & $\sqrt{ }$ & & $\sqrt{ }$ & $\sqrt{ }$ \\
\hline \multicolumn{5}{|l|}{ HK } \\
\hline Student teacher C & $\sqrt{ }$ & $\sqrt{ }$ & $\sqrt{ }$ & $\sqrt{ }$ \\
\hline Student teacher D & & $\sqrt{ }$ & & $\sqrt{ }$ \\
\hline \multicolumn{5}{|l|}{ MK } \\
\hline Student teacher E & $\sqrt{ }$ & & $\sqrt{ }$ & $\sqrt{ }$ \\
\hline Student teacher F & $\sqrt{ }$ & $\sqrt{ }$ & $\sqrt{ }$ & $\sqrt{ }$ \\
\hline \multicolumn{5}{|l|}{ FB } \\
\hline Student teacher G & $\sqrt{ }$ & $\sqrt{ }$ & $\sqrt{ }$ & $\sqrt{ }$ \\
\hline Student teacher H & & $\sqrt{ }$ & & $\sqrt{ }$ \\
\hline
\end{tabular}

\section{Teaching Facilities}

The first difficulty faced by the student teachers was the lack of teaching facilities. Different from schools, hotels are not prepared for education. Though there are many rooms in the hotel that can be used for teaching practicum, the rooms are actually meant for business purposes. Thus, all the rooms, including meeting rooms, can be fully occupied. This is what happened when our student teachers did their practicum. When the hotel was in its peak season, the rooms were all occupied and the student teachers should teach in any room available with limited teaching equipment provided. This condition made the teaching-learning process not effective. Excerpt 1,2,3 and 4 are some of the student teachers' expression taken from their reflections.

\section{Excerpt 1}

"The class was held in laundry room. The room was very small and the students did not enjoy the learning process because the room was not comfortable for learning." (student teacher B). 


\title{
Excerpt 2
}

"The hotel only provided a small office for our teaching, which has no place to use LCD projector or even a whiteboard." (Student teacher C).

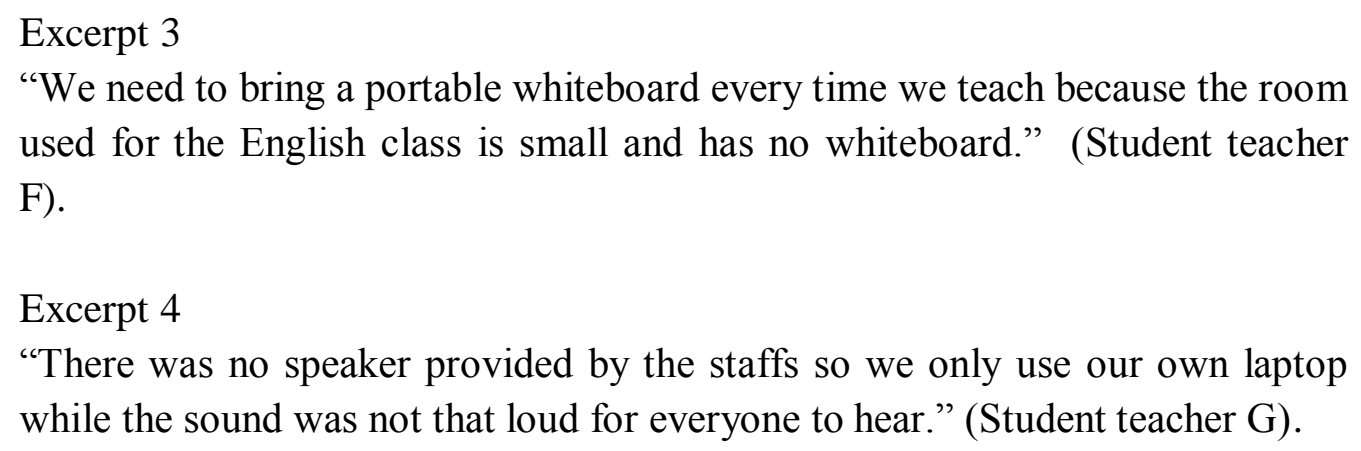

"We need to bring a portable whiteboard every time we teach because the room used for the English class is small and has no whiteboard." (Student teacher F).

\section{Excerpt 4}

"There was no speaker provided by the staffs so we only use our own laptop while the sound was not that loud for everyone to hear." (Student teacher G).

The condition had made the student teachers changed some activities in their lesson plan as there are only limited activities can be done in the small rooms that they used for teaching. As a result the teaching and learning activities became less interesting.

\section{Time Management}

The next difficulty faced by the student teachers is that the hotel staffs do not have good time management. They often come late and skip the classes. This had made the student teachers feel very confuse. While the student teachers had prepared the lesson plan for one meeting lasted two hours, they rarely can finish the lesson, like what student teacher D expressed in excerpt 5

\section{Excerpt 5}

The plans that we made to be done in the teaching session could not be done well because less number of hotel staff came while we expected more to do the activities that we had planned beforehand."'(student teacher D)

Some of the student teacher expressed that they felt demotivated to teach since sometimes there were only few hotel staff came to class. This can be seen from excerpt 5 and 6.

\author{
Excerpt 6 \\ "There were only two hotel staffs joined the class because there were a lot of \\ them who took the day-off."(student teacher F)

\section{Excerpt 7} \\ "I feel demotivated when teaching because the number of the hotel staff joining \\ my class was a half of the previous meeting." (student teacher $\mathrm{H}$ )
}




\section{Different Levels of Proficiency}

English courses usually require their students to take a placement test because it is easier for teachers if they can teach students with similar levels of proficiency in a class. However, in the teaching English to the hotel staffs our student teachers were asked to teach all of the hotel staff with no regard to their level of English proficiency. What happened in the teaching and learning process as the consequences were explained by some student teachers as can be seen from excerpt 8 and 9 .

\section{Excerpt 8}

"The participants appeared to have different problems in learning English. Some of them understand the meaning the words but not yet able to say it properly, some of them and some other did not even understand the meaning of the words of the conversation they were practicing." (student teacher A)

\section{Excerpt 9}

The hotel staffs sometimes made fun of some friends who could not pronounce English words correctly or cannot do the tasks given by the student teachers." (student teacher C)

\section{Self-Efficacy}

Another difficulty mentioned by all of the student teachers in teaching English for hotel staff is that many of the learners, the hotel staffs, have low self-efficacy in learning English. Bandura, (1994) defines self-efficacy as"people's beliefs about their capabilities to produce designated levels of performance that exercise influence over events that affect their lives". This means the learners do not have enough confidence in learning English. The do not have strong believe that they can master English as it was expressed in excerpt 10, 11.

\section{Excerpt 10}

"They don't think they will be able to talk in English well because they think they are too old to learn a second language."(student teacher B)

\section{Excerpt 11}

"Many of the hotel staffs did not feel that their pronunciations were good that they afraid of speaking" (student teacher D) 
Meanwhile, according to Genç et. al. (2016) student's beliefs about language learning are affected by their English self-efficacy. This means student teachers need to help the hotel staff to think positively about their capability of learning English. This, however, is not something simple to do. As can be seen in Excerpt 12, a student teacher expressed how difficult it is to motivate others in language learning.

\section{Excerpt 12}

"It was really hard to convince some hotel staffs that they are able to learn English, that they can do the task in learning the language. I had tried to talk to them personally about it, but it seemed that it did not work." (student teacher F)

\section{Conclusion}

The study was aimed at finding the difficulties in teaching English to hotel staff. There were four difficulties found in the study. They are teaching facilities, time management, different levels of English proficiency, and low self-efficacy. None of the difficulties is included in TESP difficulties which are related to the teachers. A further study can be done for this particular category of TESP difficulties. The findings of the study are expected to be a consideration for student teachers who wish to do their teaching practicum in hotels. 


\section{References}

Bandura, A. (1994). Self Efficacy. (V. S. Ramachaudran, Ed.) Bandura, A. (1994). Self-efficacy. In V. Encyclopedia of human behavior (Vol. 4, pp. 71-81). New York: Academic Press., 4, 71-81.

Basturkmen, H. (2006). Ideas and Options in English for Specific Purposes. Marwah, New Jersey: Lawrence Erlbaum Associates.

Basturkmen, H. (2017). ESP teacher education needs. Language Teaching, 1-13.

Belcher, D. (2009). What ESP Is and Can Be:An Introduction. In D. Belcher (Ed.), English for Specific Purposes in Theory and Practice (pp. 1-20). Michigan: Michigan ELT.

Bolton, G. (2009). Reflection and Reflexibility: What and Why. Retrieved July 27, 2017, from sagepub.com: https://uk.sagepub.com/sites/default/files/upmbinaries/32441_01_Bolton_3e_Ch_01.pdf

Bracaj, M. M. (2014). European Scientific Journal. Teahing English for Specific Purpose, 10(2), 40-49.

Dudley-Evans, A., \& St. John, A. (1998). Developments in ESP: A multi-disciplinary approach. Chambrigde: Cambridge University Press.

Dudley-Evans, T. (1998). An Overview of ESP in the 1990s. The Japan Conference on English for Specific. Purposes Proceedings, (pp. 5-11). Aizuwakamatsu City, Fukushima.

Fălăuş, A. (2016). The current difficulties of teaching ESP.

Genç, G., Kuluşakl, E., \& Aydın, S. (2016). Exploring EFL Learners' Perceived Self-efficacy and Beliefs on English Language Learning. the Australian Journal of Teacher Education, 41(2). 
Hancock, B., Windridge, K., \& Ockleford, E. (2009). An Introduction to Qualitative Reseach. The NIHR RDS EM / YH.

Hoa, N. T., \& Mai, P. T. (2016). Difficulties in Teaching English for Specific Purposes: Empirical Study at Vietnam Universities. Higher Education Studies, Vol 6.

Huang, C.-s. (2008). English Curriculum Planning for Hospitality. 2008 International Conference of Applied Foreign Languages, , (pp. 138-140).

Hutchinson, T., \& Waters, A. (1992). English for Specific Purposes: A learning centered approach. Chambrige: Cambridge University Press.

Hutchison, T., \& Waters, A. (1987). English for Specific Purposes: a learner-centred approach. England: Chambrigde University Press.

Lin, C.-H., Wu, W.-C., \& Huang, Y.-T. (2013). English for Specific Purposes (ESP) for Hospitality College Students and Hotel. International Journal of Education and Research, 1.

Snape, D., \& Spencer, L. (2003). The Foundation of Qualitative Research. In J. Ritchie, \& J. Lewis, Qualitative Reseach Practice, A Guide for Social Science Students and Researchers (pp. 1-10). London: SAGE Publication.

Zahedpisheh, N., Abu bakar, Z. B., \& Saffari, N. (2017). English for Tourism and Hospitality Purposes (ETP). English Language Teaching, 10(9). 